УДК 343.98

Ю. О. Гресь

\title{
РІВНІ ТЕХНОЛОГІї РЕАЛІЗАЦІї ДІЯЛЬНОСТІ 3 РОЗСЛІДУВАННЯ ЗЛОЧИНІВ
}

Постановка проблеми. Діяльність із розслідування злочинів є специфічним видом суспільної діяльності, складником об'єкта вивчення криміналістики. Вона полягає у пізнанні подій протиправного характеру за допомогою відповідних засобів, методів і прийомів, що не суперечать вимогам законодавства та реалізуються у визначених ним формах. У фiлософських словниках поняття «діяльність» тлумачиться як певний спосіб відтворення соціальних процесів, самореалізації людини, ії зв’язків з оточуючим світом [1, с. 236]. Наукові положення та рекомендації, що розробляються в межах усіх розділів криміналістики, мають своєю метою належне теоретичне забезпечення діяльності з розслідування злочинів актуальним, дієвим та ефективним комплексом прийомів, методів та засобів його здійснення.

Виклад основного матеріалу дослідження. У криміналістичній літературі, починаючи від етапу зародження науки, вченими завжди приділялася значна увага визначенню сутності діяльності з розслідування злочинів, характеристиці іï особливостей, структурі, засадам та формам реалізації, про що свідчить чималий науковий доробок, присвячений окресленій тематиці [2-11].

Питання визначення рівнів організації і здійснення розслідування неодноразово обговорювалось у криміналістичній літературі. Роботи, присвячені аналізу особливостей реалізації діяльності з розслідування злочинів, завжди у своїй структурі містили питання, що стосувалися форм і рівнів реалізації такого специфічного виду суспільної діяльності.

Л.Д. Самигін, досліджуючи структуру діяльності з розслідування злочинів, зробив висновок про можливість виокремлення таких їі рівнів здійснення.

Базовий, тобто технологічний рівень, який, на думку вченого, складається із системи технологічних операцій із тими чи іншими об'єктами 3 використанням певних технічних методів, прийомів, способів або засобів. Він розглядає такі операції як структурні елементи, що є окремими слідчими діями. 
Середній рівень здійснення розслідування - це тактичний рівень, у межах якого здійснюється організація та проведення слідчих дій і тактичних операцій.

Верхній рівень - стратегічний рівень розслідування - відображає діяльність слідчого та інших учасників розслідування, що пов'язана з організацією і проведенням розслідування загалом і на певних його етапах зокрема [10, c. 23-24].

Р.С. Бєлкін спробував проаналізувати структуру діяльності з розслідування злочинів через призму організаційно-управлінського підходу. Вчений розглядав чотири рівні організації розслідування.

Перший рівень - це рівень державно-правовий, об'єктом якого є розслідування як специфічний вид діяльності всіх уповноважених на іï здійснення державних органів.

Другий рівень організації розслідування - це управлінський рівень, що відображає діяльність із розслідування злочинів окремого відомства - органів внутрішніх справ, що полягає в організації вертикальної та горизонтальної структури цих органів, забезпеченні їх єдності у ході реалізації кримінальної політики держави, форм, засобів та методів розкриття та розслідування злочинів.

Третій рівень, тобто рівень організації розслідування конкретного злочину, - це методичний рівень, для якого характерним є створення оптимальних умов визначення і застосування рекомендацій криміналістичної методики, що будуть найбільш ефективними і доцільними в конкретній слідчій ситуації.

Останній четвертий рівень - це рівень тактичний, що полягає в організації та проведенні окремих слідчих дій, тактичних операцій чи організаційно-технічних заходів. Саме на цьому рівні вирішуються питання, пов'язані $з$ вибором та застосуванням найбільш ефективних і доцільних ситуаційно зумовлених тактичних і техніко-криміналістичних прийомів і засобів, спрямованих на досягнення мети проведення слідчої дії [12, c. $15-16]$.

B.Є. Корноухов зробив спробу дослідити структуру діяльності з розслідування злочинів через призму інформаційно-пізнавального підходу. Тобто вчений визначив відповідні рівні застосування засобів пізнання у ході здійснення розслідування. дій.

До першого рівня засобів пізнання він відносить проведення слідчих

Другий рівень засобів пізнання у ході здійснення розслідування становлять тактичні прийоми та їх комбінації, що застосовуються під час проведення слідчих дій.

Третій рівень утворюють науково-технічні засоби та технічні прийоми ї застосування.

Четвертий рівень засобів пізнання, що застосовуються під час проведення розслідування, учений визначає як рівень застосування експертних методик. 
П'ятий рівень засобів пізнавальної діяльності утворюють тактичні операції, що спрямовані на вирішення конкретних тактичних завдань.

Шостий рівень, на думку автора, становлять такі специфічні засоби пізнання, як програмні засоби, що розробляються на основі використання EOM, комп'ютерних програм тощо [13, с. 391-400].

О.А. Чебуренков, який присвятив значну увагу проблемі дослідження загальнотеоретичних основ діяльності з розслідування злочинів, визначає, що у процесі розслідування можна виокремити три рівні такої діяльності, серед яких він називає:

- стратегічний рівень, тобто рівень організації і проведення розслідування злочинної події загалом;

- тактичний рівень, який передбачає прийняття і реалізацію рішень, пов'язаних із плануванням, підготовкою та проведенням окремих слідчих дій, тактичних операцій;

- технологічний рівень, який, за поглядами вченого, охоплює питання прийняття та реалізації рішень у межах конкретних технологічних операцій, що входять у певну слідчу дію як ії складові частини [14, с. 9-10].

Досліджуючи теоретичні засади формування технологічного підходу в криміналістиці, аналізуючи та узагальнюючи способи реалізації слідчих технологій під час здійснення розслідування, А.А. Барцицька запропонувала класифікувати їх на три види. Визначені авторкою види слідчих технологій перебувають у діалектичному зв'язку з різними за характером видами слідчої діяльності та більшою мірою відображають рівні їх застосування, аніж просто позначають види, зокрема:

1) визначення технології застосування техніко-криміналістичних засобів, що знаходить свою реалізацію як елемент структури слідчих дій та їх комплексів;

2) визначення технології проведення окремих сідчих дій;

3) визначення технології розслідування злочинів, що полягає в особливостях реалізації окремих методик розслідування [15, с. 56].

Наведені підходи до визначення структури діяльності з розслідування злочинів вказують на внутрішню структурованість і складність цієї діяльності. Сьогодні криміналістичні дослідження спрямовані на вироблення нових концепцій та підходів до вивчення такої діяльності з метою формування цілісного розуміння та багаторівневого забезпечення іiі практичного здійснення.

Однією із сучасних тенденцій розвитку криміналістики є використання технологічного підходу та його розвиток як у науці криміналістики загалом, так і в межах окремих їі розділів [16, с. 58]. Досліджуючи особливості процесу розслідування через призму технологічного підходу, видаться доцільним говорити про можливість виокремлення рівнів технології реалізації діяльності з розслідування злочинів. Виокремлення технологічних рівнів нерозривно пов'язане із завданнями, вирішення яких вони забезпечують, що, у свою чергу, впливає на складність та багатоелементність таких дій. На нашу думку, необхідно виокремити такі чотири рівні технології здійснення розслідування: 
- перший (базовий) рівень, що полягає у реалізації окремих алгоритмів дій слідчого під час підготовки і проведення конкретних слідчих (розшукових) дій та негласних слідчих (розшукових) дій. Ці алгоритми дій спрямовані на забезпечення вирішення тактичних завдань, пов'язаних з окремими етапами здійснення слічих дій. Такі алгоритми можуть бути спрямовані на реалізацію окремих тактичних прийомів чи їх комплексів, застосування техніко-криміналістичних засобів, забезпечення певних умов належного здійснення слідчої діяльності тощо;

- другий рівень - це рівень реалізації програм слідчих (розшукових) дій та негласних слідчих (розшукових) дій. Цей рівень технології здійснення розслідування пов'язаний із вирішенням тактичних завдань, спрямованих на пошук нової криміналістично значущої інформації або перевірку вже наявної. Програма певної слідчої дії є науково обгрунтованою технологічною моделлю провадження слідчої дії у конкретному розслідуванні, що передбачає комплекс послідовних та взаємопов'язаних дій слідчого (певних алгоритмів) на всіх етапах іiі проведення, що спрямовані на вирішення конкретних тактичних завдань [17]. Важливою особливістю реалізації програм слідчих дій на цьому рівні є існування реальної можливості вирішення поставленого завдання шляхом проведення конкретної слідчої дії. Такі програми $є$ ситуативно зумовленими та передбачають існування певної альтернативи дій слідчого [18, с. 137-138];

- третій рівень - це рівень реалізації тактичних операцій на відповідному етапі проведення розслідування. Характерною властивістю технології здійснення розслідування на цьому рівні $є$ послідовне та поетапне вирішення завдань проміжного характеру шляхом реалізації комплексу алгоритмічних дій, спрямованих на досягнення кінцевої мети тактичної операції. Тактична операція зазвичай є складною формою реалізації слідчої діяльності, що поєднує у собі у вигляді комплексу однорідні чи різнорідні слідчі дії та оперативно-розшукові заходи. При цьому у структурі тактичної операції як певному різновиді криміналістичної технології [19, с. 238] послідовність слідчих дій є чітко визначеною, а жодна слідча дія не може бути замінена на іншу [20, с. 492];

- четвертий (загальний) рівень - це рівень загальної технології розслідування. Цей рівень діяльності з розслідування злочинів пов'язаний із визначенням технології розслідування певного злочину з використанням положень конкретних видів криміналістичних методик. Рівень загальної технології розслідування передбачає побудову певної моделі конкретного розслідування, яка повинна містити систему завдань тактичного і стратегічного рівня. Саме в рамках такої моделі знаходять своє місце технологія реалізації тактичних операцій, програми проведення окремих слідчих (розшукових) дій та негласних слідчих (розшукових) дій, належна реалізація яких пов'язана із застосуванням відповідних алгоритмів дій слідчого та інших учасників слідчих дій і тактичних операцій.

Висновки. 3 огляду на вищесказане необхідно зазначити, що положення технологічного підходу займають усе міцнішу позицію у криміналістиці. 
Певні технологічні аспекти властиві діяльності слідчого на різних рівнях iï реалізації, що в жодному разі не виключає евристичного іiі складника. Характерною властивістю криміналістичної технології, що відрізняє ії від технології у суто технічному значенні, $€$ те, що в криміналістиці вона має відносно жорсткий характер. Зумовлено це саме середовищем іiі реалізації, тобто діяльністю з розслідування злочинів, на характер та здійснення якої завжди впливає людський фактор: слідчий як специфічний суб’єкт їі реалізації - з одного боку, та злочинець як певним чином зацікавлена особа, яка намагається прямо чи опосередковано впливати на розслідування, - з іншого. Проте закономірності, що властиві здійсненню розслідування на різних його рівнях, потребують пильної уваги та наукового дослідження з метою розробки якісних криміналістичних рекомендацій, що б задовольняли потреби слідства. Використання технологічного підходу у криміналістичній науці дозволяє по-новому підійти до проблем слідчої діяльності та поповнити арсенал слідчого науковими рекомендаціями дещо нового характеру.

\section{Література}

1. Современный философский словарь / под общей ред. В.Е. Кемерова. - 2-е изд., испр. и доп. - Лондон - Франкфурт-на-Майне - Париж - Люксембург - М. - Минск : ПАНПРИНТ, 1998. - 1064 c.

2. Аленин Ю.П. Выявление и расследование очагов преступлений: теория и практика : [монография] / Ю.П. Аленин ; Юрид. ин-т Одес. гос. ун-та им. И.И. Мечникова. - Одесса : Юрид. ин-т ОГУ, 1996. - 267 с.

3. Доспулов Г.Г. Оптимизация предварительного следствия / Г.Г. Доспулов ; отв. ред. В.И. Попов. - Алма-Ата : Изд-во «Наука» КазССР, 1984. - 208 с.

4. Кузьмичев В.С. Теория и практика следственной деятельности : [монография]/ В.С. Кузьмичев. - К. : НВТ «Правник», 1997. - 246 с.

5. Ларин А.М. От следственной версии к истине / А.М. Ларин. - М. : Юрид. лит-ра, 1976. $-200 \mathrm{c}$.

6. Ларин А.М. Расследование по уголовному делу. Планирование, организация / А.М. Ларин. - М. : Юрид. лит-ра, 1970. - 224 с.

7. Лузгин И.М. Методологические проблемы расследования / И.М. Лузгин. - М. : Юрид. лит-ра, 1973. - 216 с.

8. Лукашевич В.Г. Проблеми оптимізації діяльності з розслідування злочинів / В.Г. Лукашевич / / Теоретичні та практичні проблеми використання можливостей криміналістики і судової експертизи у розкритті й розслідуванні злочинів. - К. : УАВС, 1996. - С. 17-19.

9. Медведев Н.Н. Теоретические основы расследования : [учеб. пособ.] / Н.Н. Медведев. Краснодар : Изд-во Кубанского гос. ун-та, 1977. - 103 с.

10. Самыгин Л.Д. Расследование преступлений как система деятельности / Л.Д. Самыгин. М. : Изд-во МГУ, 1989. - 182 с.

11. Чебуренков А.А. Основы теории расследования : [монография] / А.А. Чебуренков. М. : Юрлитинформ, 2010. - 176 с.

12. Белкин Р.С. Очерки криминалистической тактики : [учеб. пособ.] / Р.С. Белкин. - Волгоград : Изд-во ВСШ МВД РФ, 1993. - 200 с.

13. Курс криминалистики. Общая часть / отв. ред. В.Е. Корноухов. - М. : Юристъ, 2000. - 784 с.

14. Чебуренков А.А. Общетеоретические положения и практические аспекты криминалистической тактики / А.А. Чебуренков. - М. : Юрлитинформ, 2008. - 240 с.

15. Тіщенко В.В. Теоретичні засади формування технологічного підходу в криміналістиці : [монографія] / В.В. Тіщенко, А.А. Барцицька ; НУ «ОЮА». - Одеса : Фенікс, 2012. - 198 с.

16. Шепитько В.Ю. Изменчивость криминалистики в XXI веке и её задачи в современных условиях / В.Ю. Шепитько / / Криміналістика XXI століття : матер. Міжнар. наук.- практ. конф. (м. Харків, 25-26 листоп. 2010 р.). - С. 55-59. 
17. Гресь Ю.О. Особливості побудови типової технологічної моделі слідчої (розшукової) дії / Ю.О. Гресь / / Порівняльно-аналітичне право. - 2016. - № 2. - С. 200-203. - [Електронний ресурс]. - Режим доступу : http:/ / www.pap.in.ua/2_2016/60.pdf.

18. Хань О.О. Технології програмування провадження окремих слідчих (розшукових) дій / О.О. Хань / / Теорія та практика судової експертизи і криміналістики. - 2014. - Вип. 14. C. $134-139$.

19. Шевчук В.М. Технологія тактичної операції як різновид криміналістичних технологій / В.М. Шевчук / / Вісник НАПрН України. - 2013. - № 4 (75). - С. 235-242.

20. Криминалистика : [учеб. для вузов] / Т.В. Аверьянова, Р.С. Белкин, Ю.Г. Корухов, Е.Р. Россинская. - 3-е изд., перераб. и доп. - М. : Норма, 2007. - 990 с.

\section{А но т а ц і я}

Гресь Ю. О. Рівні технології реалізації діяльності з розслідування злочинів. Стаття.

Статтю присвячено висвітленню наукових підходів до визначення рівнів здійснення слідчої діяльності. У межах дослідження технологічного підходу в криміналістиці автором розглянуто можливість визначення рівнів технології реалізації діяльності з розслідування злочинів.

Ключові слова: слідча діяльність, діяльність із розслідування злочинів, технологічний підхід.

\section{Анн о т а ция}

Гресь Ю. О. Уровни технологии реализации деятельности по расследованию преступлений. - Статья.

Статья посвящена освещению научных подходов к определению уровней осуществления следственной деятельности. В рамках исследования технологического подхода в криминалистике автором рассмотрена возможность определения уровней технологии реализации деятельности по расследованию преступлений.

Ключевые слова: следственная деятельность, деятельность по расследованию преступлений, технологический подход.

\section{S u m m a r y}

Hres $Y u$. O. Levels of technological activities to investigate crimes. - Article.

The article is devoted to the coverage of scientific approaches to determining the levels of investigative activity. As part of the study of the technological approach in forensics, the author examined the possibility of determining the levels of technology for investigating crimes.

Key words: investigative activities, crime investigation, technological approach. 